\title{
The mericarp of the halophyte Crithmum maritimum (Apiaceae): structural features, germination, and salt distribution
}

\author{
Abdallah Atia ${ }^{1}$, Ahmed Debez ${ }^{1,2}$, Zouhaier BARhoumi ${ }^{1}$, Ettore PACINI ${ }^{3}$, Chedly Abdelly ${ }^{1}$ \\ \& Abderrazak SMAOUI ${ }^{1 *}$ \\ ${ }^{1}$ Laboratoire d'Adaptation des Plantes aux Stress Abiotiques, Centre de Biotechnologie, Technopole de Borj Cédria, BP 901, \\ Hammam-Lif, 2050, Tunisie; e-mail: abderrazak.smaoui@yahoo.fr \\ ${ }^{2}$ Institut für Botanik, Leibniz Universität Hannover, Herrenhäuser Str.2, D-30419 Hannover, Germany. \\ ${ }^{3}$ Botany Section, Department of Environmental Biology, University of Siena, Via P.A. Mattioli 4, 53100 Siena, Italy.
}

\begin{abstract}
At maturation and during seed fall and dispersal, halophyte seeds may be subjected to invasion by salt ions. How these seeds remain viable in such hostile environments is however still unclear, depending for instance on the species and the family. In the Apiaceae, the mericarp (fruit) shows a wide range of morphological and anatomical modifications, many of which may enhance the adaptation to severe environmental conditions. Therefore, structural features, ion accumulation, and long-term floating capacity were investigated in the fruit (mericarp) of the halophyte Crithmum maritimum L. The mericarp was composed of a spongy outer coat, a secretory envelope, a thin endocarp reduced to a unicellular layer delimiting the endosperm, and an embryo. Both of the secretory canals and the endocarp adhered after complete ripening of the mericarp, while the epicarp and much of the mesocarp formed the spongy coat. Assessing long-term floating ability of the fruit under laboratory conditions revealed that even after $60 \mathrm{~d}$, more than $98 \%$ of C. maritimum L. mericarps still floated over seawater. Seed germination was delayed and reduced by the spongy coat. The X-ray microanalysis revealed that the spongy coat and the secretory canals contained essentially $\mathrm{Cl}$ and $\mathrm{Na}$, while seeds, i.e. endosperm and embryo, accumulated mostly $\mathrm{Mg}, \mathrm{K}$ and P. In a subsequent experiment designed to simulate salt leaching by rain, most of the salt accumulated in the spongy coat and seeds was released after $2 \mathrm{~h}$ imbibition in distilled water. Taken together, these results highlight the protective role of the mericarp and the likely involvement of this structure in the seed dispersal of C. maritimum L. This may ultimately have eco-physiological implications explaining the successful establishment of this halophyte in its native saline biotopes.
\end{abstract}

Key words: Crithmum maritimum L.; dispersal; fruit; spongy coat; X-ray microanalysis.

\section{Introduction}

In the Apiaceae, the mericarp (fruit) is characterised by several morphological and anatomical traits, many of which are likely involved in the seed dispersal phenomenon (Spalick et al. 2001). Apiaceae fruit is typically a schizocarp with two-ribbed mericarps. The mericarp is composed of an outer coat with five separating primary ribs and four valleculae, the latter sometimes divided by a secondary rib. The presence and the number of secretory canals are highly variable in this family (Guinard 1974). Seed dispersal is a major mechanism of plant adaptation to environmental constraints (Shen et al. 2007). Dispersal of vegetative diaspores, fruits and seeds depends on abiotic (wind, water, rain) and biotic vectors (Chang et al. 2005). Hydrochory, or dispersal by water, is an important aspect of vegetation dynamics of species growing near streams, rivers, oceans, and seas (Wolters et al. 2004). In angiosperms, seed protection is ensured by testa. However, for species that have an indehiscent fruit, the whole fruit may mediate the protection of seeds (Bewly \& Black 1983). During the period of embryonic development, halophytes avoid injury upon the exposure to ionic and osmotic stress by restricting transport of salt into seeds (Khan et al. 1985; Ghars et al. 2006; Debez et al. 2008). However, at maturation and during seed fall and dispersal, halophyte seeds may be subjected to invasion by salt ions. How these seeds remain viable in such hostile environments is however still unclear. It is assumed that the external part of the fruit, i.e. seed coat and testa, protects the embryo.

Crithmum maritimum L. (Apiaceae) is a perennial halophyte typical of the rocky Mediterranean coasts (Abdelly et al. 2006). Recent studies have shown that moderate salinities $(200 \mathrm{mM} \mathrm{NaCl})$ inhibit its germination without altering seed viability (Atia et al. 2006) and that the plant growth at the vegetative stage remains unaffected up to $300 \mathrm{mM} \mathrm{NaCl}$ (Ben Amor et al. 2005). In C. maritimum L., the fruit is indehiscent, and composed of a spongy outer coat. At the maturation stage, this structure may have an important role

\footnotetext{
* Corresponding author
} 


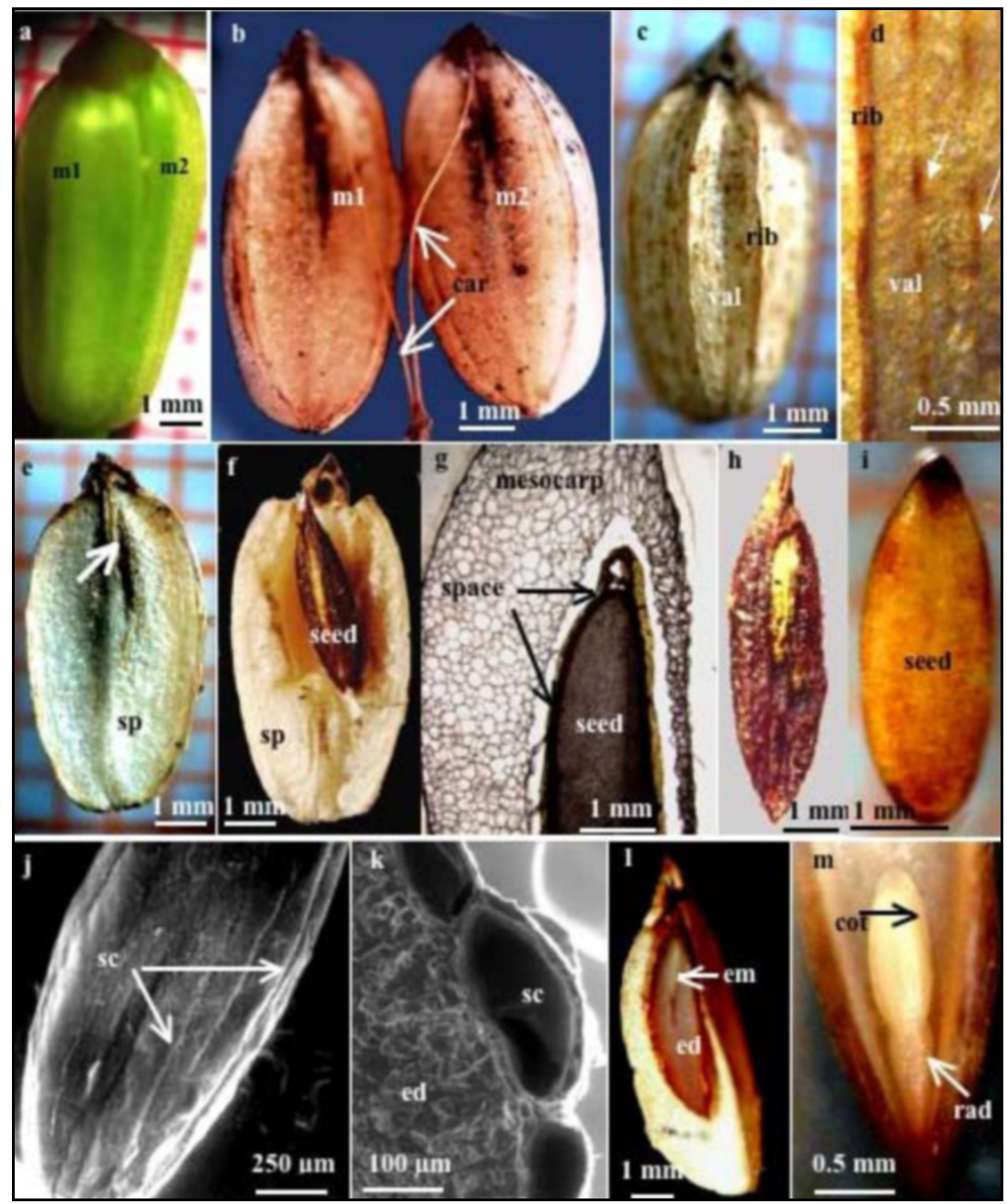

Fig. 1. a - Stereomicroscope image of immature fruit showing two mericarps ( $\mathrm{m} 1$ and $\mathrm{m} 2)$; $\mathrm{b}$-Fruit at maturity stage. Note the two mericarps related only by carpophores (car); c - Dorsal face of mature fruit showing the valleculae (val) separated by the rib (rib); $\mathrm{d}-$ A detailed view of valleculae (val) separated by the rib (rib) showing a discontinuous brown line (arrows); e - Ventral face of mature fruit, with a spongy aspect ( $\mathrm{sp}$ ) and a translucent aspect at upper part, showing the brown seed (arrow). $\mathrm{f}-\mathrm{A}$ dissected fruit showing the seed, easy detachable from the spongy coat. Note that the length of fruit was the double of seed; $g$ - Longitudinal section of the fruit, showing the space between the seed and the spongy coat; $h$ - The ventral face of seed covered with the secretory envelope layers; $\mathrm{i}$ - The true seed surface after the removal of the secretory envelope; $j$ - SEM micrograph of the seed surface, showing the secretory canals (sc); $\mathrm{k}$ - Seed transversal section showing the secretory canals (sc) surrounding the endosperm (ed); l - Longitudinal section of the fruit showing the right position of the embryo (em) within the endosperm (ed); $\mathrm{m}$ - Embryo view within dissected seed showing the radicle (rad) and the cotyledon (cot).

in seed dispersal, salt sequestration and germination. In the present study, we address the fruit and seed structure as well as the ion distribution between the different fruit parts, and discuss their potential implications, especially with respect to seed protection, germination and plant dispersal by seawater.

\section{Material and methods}

Mericarp harvesting and germination experiments

Fully ripened mericarps were collected in December 2005 from the rocky coasts of Tabarka (N-W of Tunisia, N $36^{\circ} 57^{\prime} 12^{\prime \prime}$ E $08^{\circ} 45^{\prime} 18^{\prime \prime}$ ). Fruits were stored under dry laboratory conditions until starting the experiments in May 2006. In addition, immature fruits were collected from a group of plants at the experimental station of Borj Cedria Technopark and immediately used. Intact mericarps and seeds (mericarps with spongy coat removed) were disinfected for $5 \mathrm{~min}$ in a $3.5 \%$ calcium hypochlorite solution. Intact mericarps and seeds were then sown in $9 \mathrm{~cm}$-diameter Petri dishes (4 replicates of 25 each) and covered with a double layer of filter paper (type Filtrak) moistened with distilled water. The experiment was carried out in a growth chamber $\left(18-23^{\circ} \mathrm{C}, 8 \mathrm{~h}-16 \mathrm{~h}\right.$ dark-light). White light was produced by 5 fluorescent lamps (Type OS-RAM $40 \mathrm{~W}, 25 \mu \mathrm{mol}$ $\mathrm{m}^{-2} \mathrm{~s}^{-1}, 400-700 \mathrm{~nm}$ ). The seed and intact mericarp were considered to germinate when the radicle appeared (Côme 1982). Germination was counted on alternate days.

\section{Salt leakage experiments}

After removing the spongy coat, seeds were placed in $5 \mathrm{ml}$ distilled water (4 replicates). The water was changed after $20,40,60$ and $120 \mathrm{~min}$, and the concentration of $\mathrm{Na}^{+}$released from seeds into distilled water at each time interval was determined by a flame photometer (type Corning). 


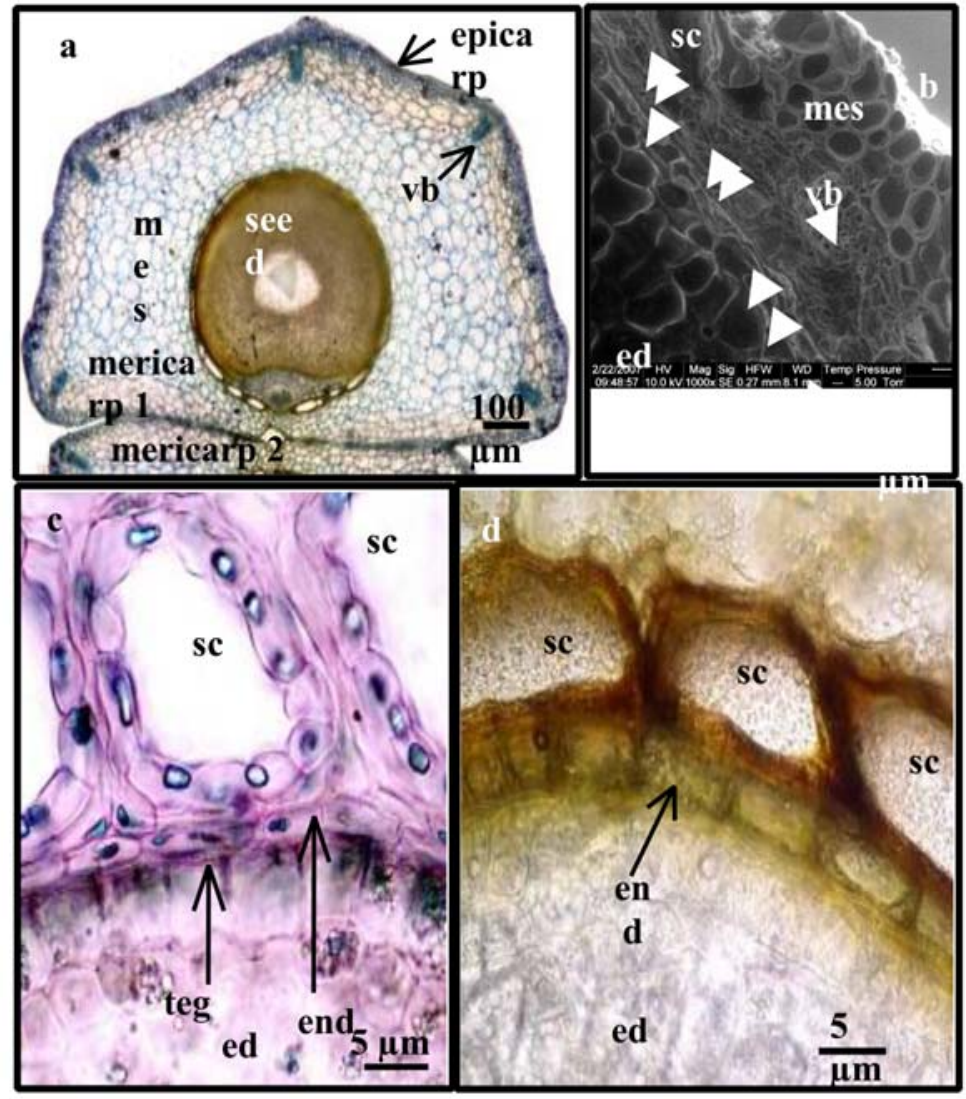

Fig. 2. a - Free hand cross section of developing fruit showing two mericarps with four valleculae, five ribs, and five vascular bundles (vb). The spongy coat is constituted by a large mesocarp (mes). Section stained by toluidine blue; b - SEM view of transversal section of a mature fruit at commissural regions showing from the outer to the inner side the mesocarp (mes), the commissural vascular bundle (vb), the secretory canals (sc), the endocarp layer (double arrows), a reduced tegument (single arrows), and the endosperm (ed); c LM view of transversal section of developing fruit showing the secretory canals (sc), the endocarp (end), a reduced tegument (teg), and the endosperm (ed); d - LM view of transversal section of a mature fruit: the endocarp (end) separates the endosperm (ed) from the secretory canals (sc) layers. Note the brown colour of condensed phenol.

\section{Structural investigations and microanalysis}

For light microscopy observations, seeds and mericarp were cut with a razor blade and stained with a mixture of toluidine blue and malachite green dyes. Mericarps and the seed surface were photographed using a stereomicroscope (Olympus). To determine the salt distribution within the fruit tissues, a Scanning Electron Microscope (SEM) FEI Quanta 200, equipped with X-ray (EDAX) system for microanalysis, was used at $15 \mathrm{kV}$ with a working distance of 10 to 11.4 $\mathrm{mm}$. The X-ray spectra for the compositional analyses were performed for the following elements: $\mathrm{Na}, \mathrm{Mg}, \mathrm{Cl}, \mathrm{P}, \mathrm{K}$, and Ca. Observations of free-hand sections of both the fruit and seed surface were also achieved.

\section{Results}

\section{Mericarp morphology and anatomy}

Structural analysis revealed that the fruit of $C$. maritimum L. is a schizocarp divided into two mericarps (Fig. 1a). At maturity, the mericarps were almost separated, remaining attached only by the carpophores (Fig. 1b). The spongy coat was the predominant tissue of the mericarp, and presented two faces: a convex dorsal face, divided into four valleculae, separated by three main ribs (Figs 1a-c). At maturity, each vallecula was festooned by several discontinuous brown lines
(Figs 1c,d). The ventral face appeared to be spongy, being translucent on the top and revealing the seed (Fig. 1e). The spongy coat, mechanically removable, allowed seeds to be collected separately (Figs 1f,g). The seed included the endosperm and an embryo, both adhering closely to the endocarp and secretory canals. The seed was attached to the spongy coat by only a few points surrounded by a large space (Fig. 1g). The seed surface was brown and rough due to the presence of attached secretory canals (Fig. 1h). The surface of the true seed was smooth when secretory canals were removed (Fig. 1i). SEM micrographs at the seed surface (Fig. 1j) and transversal section of seed (Fig. 1k) highlighted the presence of secretory canals surrounding the seed, which could be responsible for the secretion of essential oils, giving the plant its characteristic Apiaceae smell. The seed and its embryo were located at the vicinity of the commissural region (plane face) of the mericarp (Fig. 11). Longitudinal sections of imbibed seed showed right embryo with large developed endosperm (Figs 1lm).

The epicarp, consisting of small cells, formed the outer layer and the mesocarp tissue was the largest tissue, named the spongy coat (Fig. 2a). Cells of the latter were polygonal with translucent walls and numerous in- 


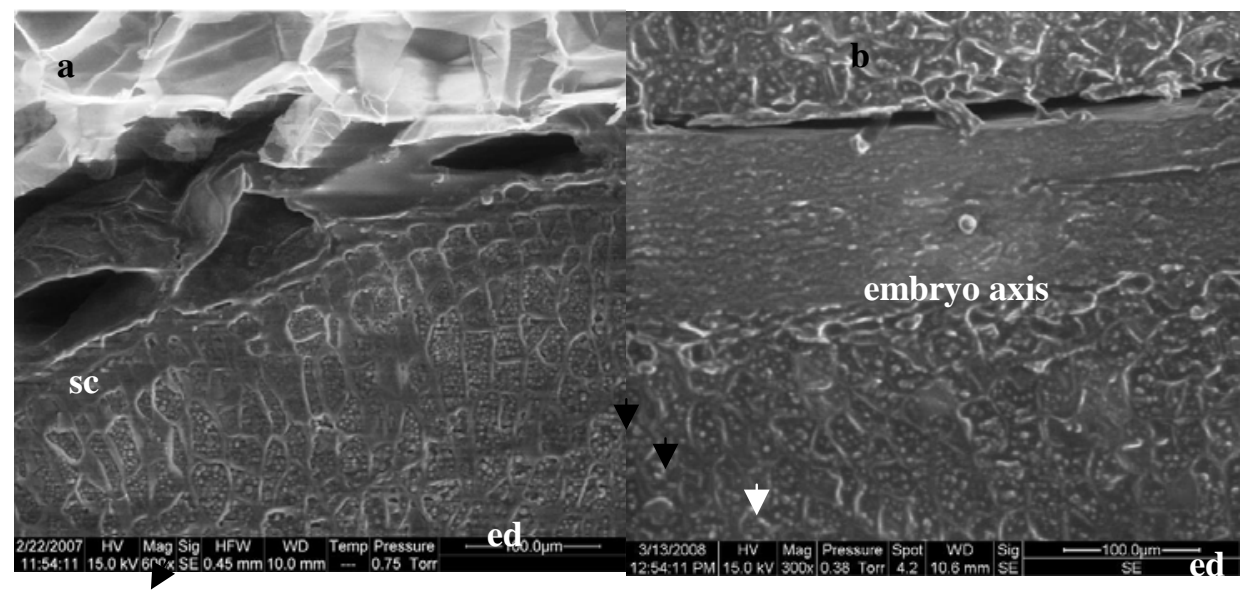

Fig. 3. a - SEM view of transversal section of a dry mature fruit showing the mesocarp, the secretory canals (sc), and the endosperm tissue (ed) with the reserve globoids (white arrows) and the cell wall (black arrows) of endosperm cell; b - SEM view of longitudinal section of dry mature seeds showing the embryo axis and the cotyledon (cot) surrounded by the large endosperm (ed).

Table 1. Results of floatability test expressed as percentage of loss of floating capacity of C. maritimum L. mericarp in distilled water and sea water over time.

\begin{tabular}{lccc}
\hline \multirow{2}{*}{ Treatment } & \multicolumn{3}{c}{ Time (days) } \\
\cline { 2 - 4 } & 0 & 30 & 60 \\
\hline Distilled water & 0 & $38.3 \pm 3.3$ & $65 \pm 9.3$ \\
Sea water & 0 & 0 & $1.7 \pm 1$ \\
\hline
\end{tabular}

tracellular spaces, conferring to them low density. Cells were smaller around the vascular bundles (Fig. 2a). Sections of the developing mericarp showed five vascular bundles close to the rib with xylem vessels adjacent to the phloem (Fig. 2a). SEM cross sections revealed large outer cells of the spongy mesocarp, a commissural vascular bundle, the secretory canals, and a single inner cell layer that represented the endocarp. The inner layer of pericarp, i.e. the endocarp, joined the secretory canals and the outer cell layer of the endosperm which may be considered a reduced seed tegument (Figs. 2b and 2c). One secretory cellular layer composed the secretory canal (Fig. 2c). At maturity, this envelope was brown, presumably due to the oxidation of the phenol compounds (Fig. 2d). SEM view of transversal section of dry mature fruit revealed the mesocarp, the secretory canals and the endosperm tissue filled with the reserve globoids surrounded by the cell wall of endosperm cell (Fig. 3a). SEM view of longitudinal section of dry mature seeds showed the embryo axis, the cotyledon and the large endosperm (Fig. 3b).

\section{Germination capacity and mericarp dispersal}

The presence of spongy coat delayed the germination process and reduced the index of germination velocity (Figs. 4a and 4b). Interestingly, even after $60 \mathrm{~d}$, the mericarps maintained a high floating capacity over seawater, only $1.7 \%$ sinking (Table 1 ), whereas $65 \%$ of the mericarps sank in distilled water. The seeds (without spongy coat) lost their capacity to float in few minutes (data, not shown).

\section{Salt leakage and ion distribution}

The salt leakage tests showed that sodium was substantially leached when the seed and the spongy coat were immersed in distilled water (Fig. 5a). $\mathrm{Na}^{+}$leached from seeds over time represented $15 \%$ to $25 \%$ of $\mathrm{Na}^{+}$leached by the spongy coat (Fig. 5b). X-ray microanalysis showed that cell walls of the cellular spongy coat accumulated high amounts of $\mathrm{Cl}, \mathrm{Na}$ and $\mathrm{K}$ (Fig. 6a). Similarly, the secretory layer accumulated $\mathrm{Cl}, \mathrm{Na}$ and $\mathrm{K}$ (Fig. 6b). The endosperm cell wall contained high amounts of $\mathrm{K}$ and $\mathrm{P}$ (Fig. 6c). The globoid reserves were rich in $\mathrm{P}, \mathrm{K}$ and $\mathrm{Mg}$ (Fig. 6d). The embryo axis was sodium and chloride-free but accumulated $\mathrm{P}, \mathrm{K}, \mathrm{Ca}$ and $\mathrm{Mg}$ (Fig. 6e).

\section{Discussion}

The fruit of Apiaceae is usually a schizocarp, consisting of two mericarps with an irregular external surface, having five primary ribs separated by four valleculae. The latter can be divided by a secondary rib. The number of secretory canals is variable in the Apiaceae (Guinard 1974). In C. maritimum L., the fruit was found to be a two-faced mericarps: the dorsal face is convex and subdivided into four valleculae separated by three main ribs. Each mericarp has five vascular bundles as in almost all other Apiaceae. Three of these are located on the dorsal side of the mericarp, and two on the lateral ribs. In the genus Choritaenia, each mericarp has seven vascular bundles (Liu et al. 2007a). The ventral face is spongy and translucent on the top, and reveals the seed (Figs 1b, 1e and 1f). According to Belzunce et al. (2005), the spongy coat may enable the seed to adapt to its native biotope.

In the present study we showed that $C$. maritimum L. mericarps had a large spongy coat, which could play an important role in seed dispersal. This assumption is strengthened by the flotation test data, which indicated that mericarps maintained a high long-term (60 d) floating capacity (only $1.7 \%$ of mericarps being totally submerged by seawater) (Table 1 ). In saline 

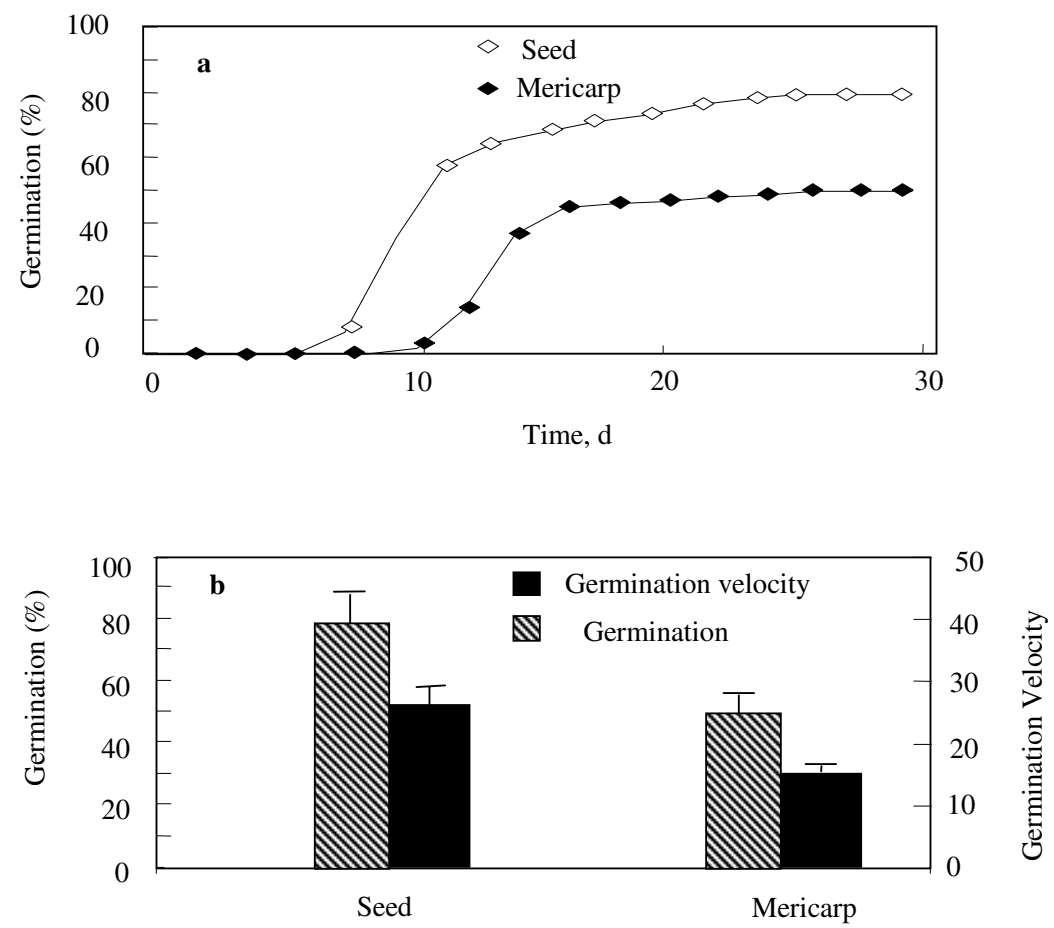

Fig. 4. a - Germination kinetics and (b) final germination percentage and index of germination velocity in mericarp and seed of $C$. maritimum L.
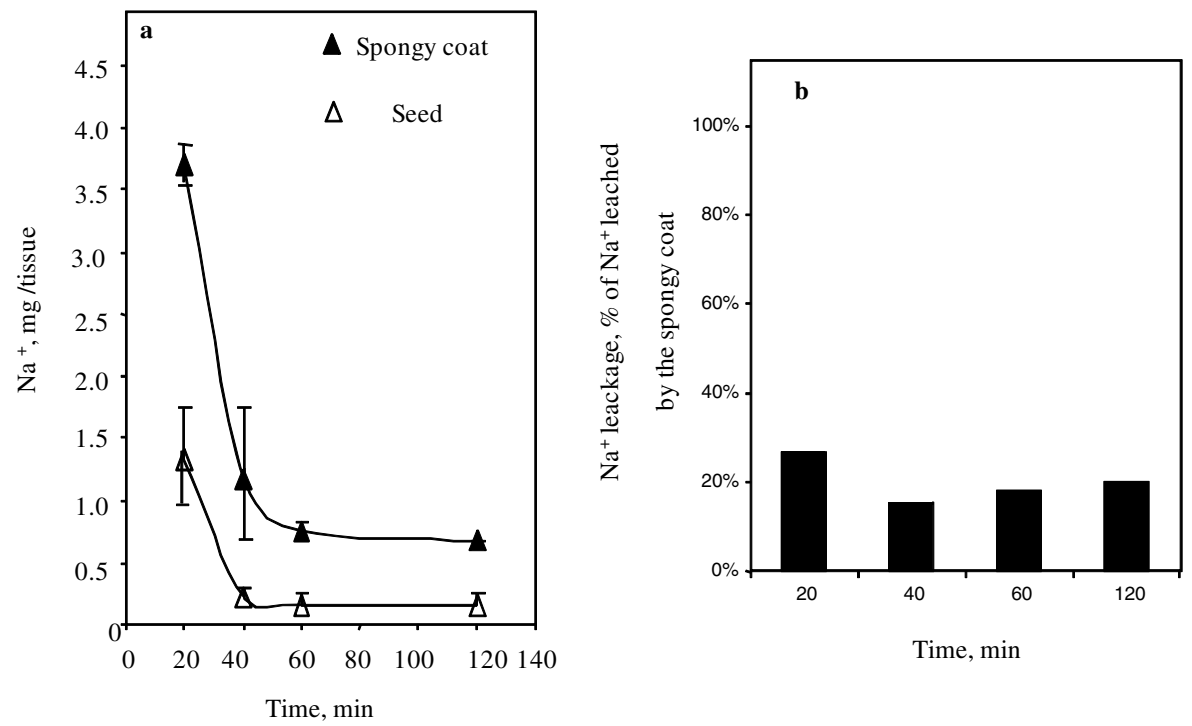

Fig. 5. a - Sodium leakage over time from the seed and the spongy coat; $\mathrm{b}$ - Sodium leakage over time from the seeds in percent of sodium leached from the spongy coat.

habitats, this characteristic is of vital importance, as it may improve the survival and adaptation to high salinity of halophytes. It has often been documented that halophyte seeds maintain viability in strong salt backgrounds until conditions became suitable for germination (Khan \& Ungar 1997; Debez et al. 2004). Consistent with previous reports in salt tolerant species, the high floating capacity of $C$. maritimum L. in seawater would contribute to the long-distance dispersal without affecting seed viability. Long-distance spreading may enhance new population establishment. In Atriplex prostrata, high hydrochory is ensured by the presence of bracteoles (Ungar \& Khan 2001). In Mertensia mar- itima, $100 \%$ of nutlets continued to float after 9 weeks, and were transported at $168 \mathrm{~km}$ per week (Skarpaas \& Stabbetorp 2001).

The seed testa or tegument is the interface between the embryo and the exterior environment. Its function for seed protection, dispersal, and survival in adverse environments is well known (Mohammed-Yasseen et al. 1994). In most of Apiaceae, the endosperm is in direct contact with the endocarp. In C. maritimum L., the thickness of the border of the external cell layer of the endosperm and the endocarp suggested a much reduced tegument. In Apiaceae, the seed may be enclosed in an endocarp, as documented in Ferula coskunii (Du- 


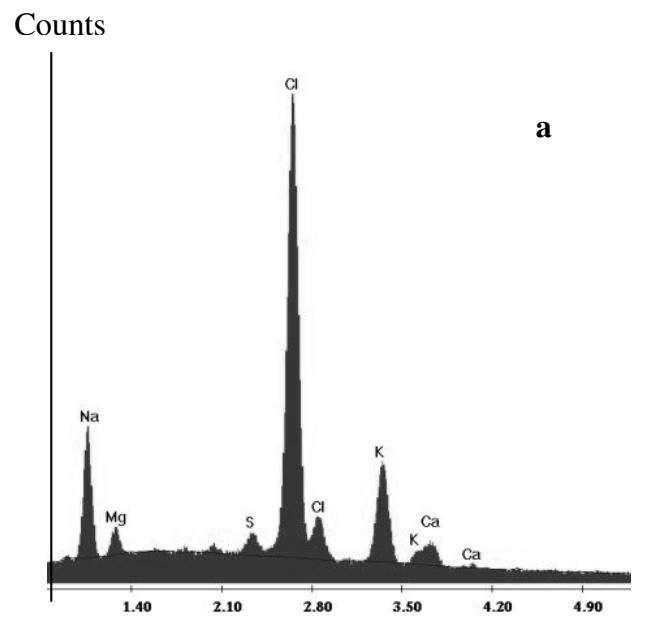

$\mathbf{k V}$

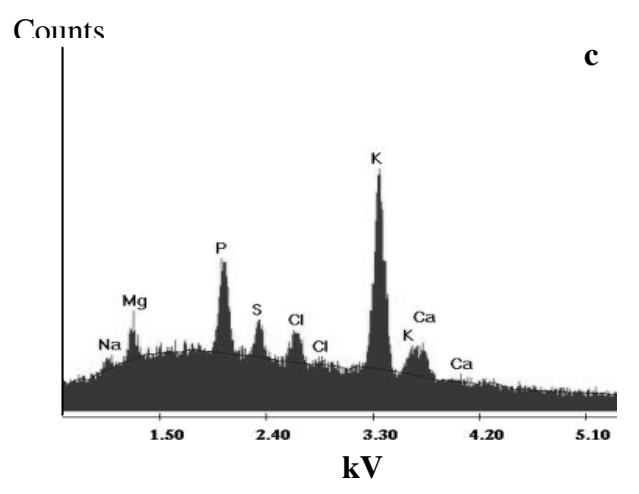

Counts

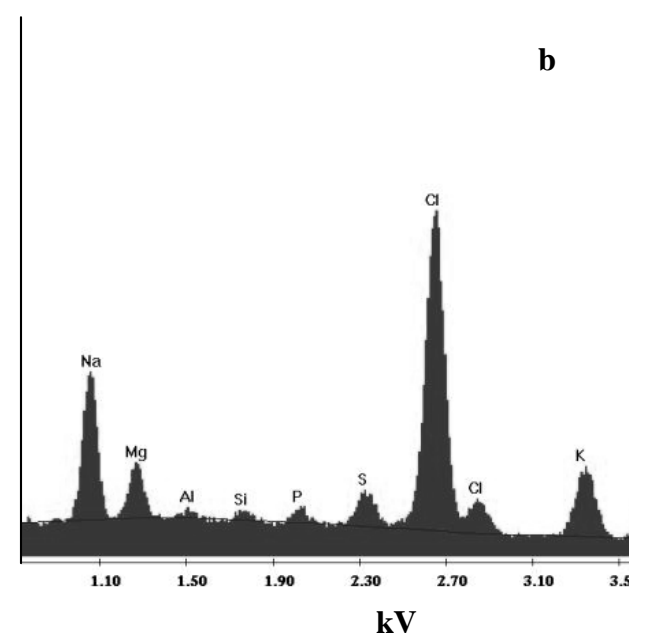

Counts

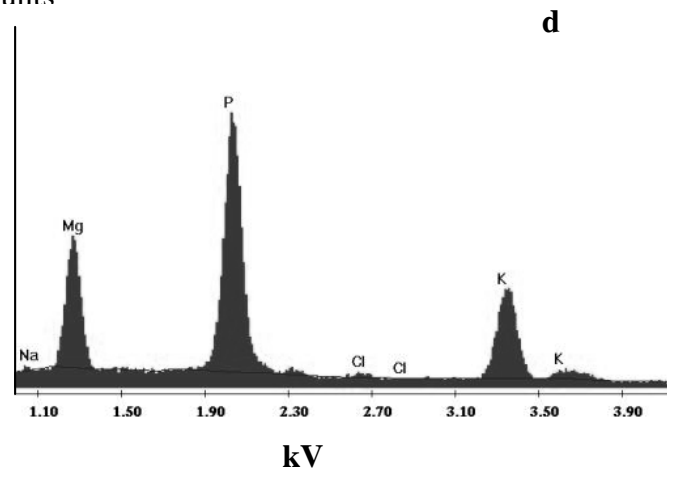

Counts

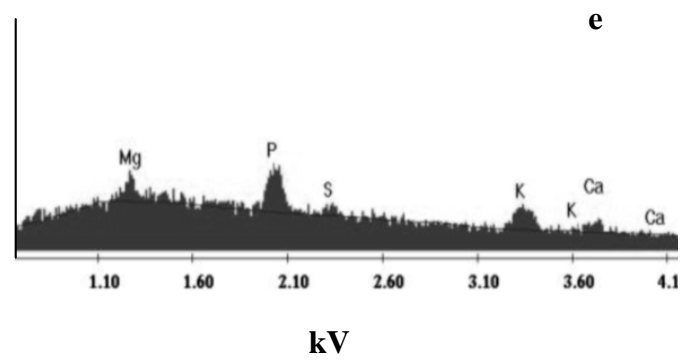

Fig. 6. a - X-ray spectra derived from the cell wall of the spongy coat; $\mathrm{b}$ - X-ray spectra derived from a secretory envelope cell; $\mathrm{c}$ - X-ray spectra derived from the endosperm cell wall; $d$ - X-ray spectra derived from reserve globoids of the endosperm; $\mathrm{e}-\mathrm{X}$-ray spectra derived from the embryo tissue.

man \& Sairo 2005), Choritaenia capensis (Liu et al. 2007a), Marlothiella gummifera (Liu et al. 2007b), and Steganotaenia araliacea (Liu et al. 2007c). In C. maritimum L., the endocarp connection to the secretory canals may efficiently cover and protect the seed. Although angiosperm seeds are generally enclosed in a testa (tegument), seeds of numerous species may have a reduced tegument, likely due to the development of a pericarp, which ensures the protection of seeds. In this case, dispersal is ensured directly by the fruit, as reported in Helianthus annuus and Lactuca sativa (Bewly \& Black 1983). In C. maritimum L., the embryo size was small as compared to the whole seed, and germination started $8 \mathrm{~d}$ after imbibition of the seed and $10 \mathrm{~d}$ after imbibition of the mericarps. The seeds are not physiologically dormant but may experience a morphological dormancy, i.e. embryos need time to grow to full size before germination. The dormancy period is the time elapsing between incubation of fresh seeds and radicle elongation (Baskin \& Baskin 2004).

Seeds are submitted in their biotope to salt fluctuations, which influence their viability and their capacity to germinate in saline conditions. Salt leakage allows germination of halophytes seeds (Ungar 1978; Debez 2004). Simulating the effect of rain on salt leakage revealed that the mericarp and seeds of $C$. maritimum $\mathrm{L}$. readily released $\mathrm{Na}^{+}$, after only $25 \mathrm{~min}$. This is consistent with previous data on Atriplex sagitatta, showing that most of the salt was leached after 2 hrs of treatment with distilled water (Bohumil \& Petr 2001). In the present study, the amount of $\mathrm{Na}^{+}$leached from the spongy coat was 5-fold higher than that leached from 
seeds. This indicates that the spongy coat accumulated more salt, probably because containing numerous intracellular spaces, which may protect seeds from the harmful salt damage. Microanalysis confirmed salt sequestration in this tissue: the secretary layer essentially accumulated sodium and chloride, whereas seed endosperm and embryo were salt-free. The outer tissues of the mericarp, i.e. the spongy coat and the secretory layer, may therefore protect the seed against ion toxicity in the absence of a very thick seed tegument. As found in C. maritimum L., previous X-ray microanalysis of Salicornia pacifica seeds showed that chloride, sodium, calcium and potassium were only accumulated in the seed coat. In Atriplex canescens, potassium was present only in the seed coat. Consistent with our findings, high concentrations of $\mathrm{P}$ and $\mathrm{K}$ were found in S. pacifica and A. canescens embryos, which were free of sodium and chloride (Khan et al. 1985). Phosphorus is an essential nutrient for embryo development and germination. Salt sequestration in the outer seed compartment avoids ion damage to the embryo (Song et al. 2005), as reported in Acacia tortilis, A. coriacea (Rehman et al. 1998), Sueada physophora and Haloxylon ammodendron (Song et al. 2005). Thus, the seed coat is more than a physical barrier reducing $\mathrm{Na}^{+}$uptake by the embryo (Rehman et al. 1998). This may explain why in saline ecosystems, halophyte seeds respond to salinity by becoming dormant (Khan \& Ungar 1997) and restricting ions, such as $\mathrm{Cl}^{-}$and $\mathrm{Na}^{+}$, to their external parts.

In conclusion, our observations confirmed that the fruit of C. maritimum L. is a dispersal unit. The spongy coat and secretory envelope may protect the seed from $\mathrm{Na}^{+}$and $\mathrm{Cl}^{-}$damage, by accumulating these harmful ions. Finally, the high floating capacity in concomitance with high germination recovery (Atia et al. 2006) may explain the long-distance seed dispersal and consequently the wide distribution of $C$. maritimum L.

\section{References}

Abdelly C., Barhoumi Z., Ghnaya T., Debez A., Ben Hamed K., Ksouri R., Ouerghi Z., Smaoui A., Huchzermeyer B. \& Grignon C. 2006. Potential utilization of halophytes for the rehabilitation and valorization of salt-affected areas in Tunisia, pp. 161-172. In: Özturk M., Waisel, Y., Khan M.A. \& Görk G. (eds), Biosaline agriculture and salinity tolerance in plants. Birkhauser Verlag, Switzerland.

Atia A., Ben Hamed K., Debez A. \& Abdelly C. 2006. Salt and seawater effects on the germination of Crithmum maritimum pp. 29-33. In: Özturk M., Waisel Y., Khan M.A. \& Görk G. (eds), Biosaline agriculture and salinity tolerance in plants. Birkhauser Verlag, Switzerland.

Baskin J.M. \& Baskin C.C. 2004. A classification system for seed dormancy. Seed Sci. Res. 14: 1-16.

Belzunce M., Navarro R.M. \& Rapoport H.F. 2005. Seed and early plantlet structure of the Mediterranean seagrass Posidonia oceanica. Aquat. Bot. 82: 269-283.

Ben Amor N., Ben Hamed K., Debez A., Grignon C. \& Abdelly C. 2005. Physiological and antioxidant responses of the perennial halophyte Crithmum maritimum to salinity. Plant Sci. 168: 889-899.

Bewly J.D. \& Black M. 1983. Physiology and Biochemistry of Seeds. Springer-Verlag, New York.
Bohumil M. \& Petr P. 2001. The effect of light quality, nitrate concentration and presence of bracteoles on germination of different fruit types in the heterocarpous Atriplex sagittata. J. Ecol. 89: 149-158.

Chang E.R., Zozaya E.L., Kuijper D.P.J. \& Bakker J.P. 2005. Seed dispersal by small herbivores and tidal water: are they important filters in the assembly of salt-marsh communities? Funct. Ecol. 19: 665-673.

Côme D. 1982. Germination, pp. 129-225. In: Mazliak, P. (Ed.), Croissance et Développement. Physiologie Végétale II. Hermann, Paris.

Debez A., Koyro HW, Grignon C., Abdelly C. \& Huchzermeyer B. 2008. Relationship between the photosynthetic activity and the performance of Cakile maritima after long-term salt treatment. Physiol. Plant. 133: $\overline{373-385}$.

Debez A., Ben Hamed K., Grignon C. \& Abdelly C. 2004. Salinity effects on germination, growth, and seed production of the halophyte Cakile maritima. Plant Soil 262: 179-189.

Duman H. \& Sairo M. 2005. A new species of Ferula (Apiaceae) from South Anatolia, Turkey. Bot. J. Linn. Soc. 147: 357361.

Ghars M.A. Debez A., Smaoui A., Zarrouk M., GrignonC \& Abdelly C. 2006. Variability of fruit and seed-oil characteristics in Tunisian accessions of the halophyte Cakile maritima (Brassicaceae), pp. 55-67. In: Khan M.A \& Weber D.J. (eds), Ecophysiology of high salinity tolerant plants. Tasks for vegetation science, Vol 40. Springer, Netherlands.

Guinard J.L. 1974. Abrégé de botanique. Masson \& C $\mathrm{C}^{\mathrm{ie}}$, Paris.

Khan M.A., Weber D.J. \& Hess W.M. 1985. Element distribution in seeds of the halophytes Salicornia pacifica var. uthansis and Atriplex canescens. Am. J. Bot. 72: 1672-1675.

Khan M.A. \& Ungar I.A. 1997. Effect of light, salinity, and thermoperiod on the germination of halophytes. Can. J. Bot. 75: 835-841.

Liu M., Wyk B.V. \& Tilney P.M. 2007a. A revision of the genus Choritaenia (Apiaceae). South Afr. J. Bot. 73: 184-189.

Liu M., Wyk B.V. \& Tilney P.M. 2007b. A revision of the genus Marlothiella (Apiaceae). South Afr. J. Bot. 73: 208-213.

Liu M., Wyk B.V. \& Tilney P.M. 2007c. Irregular vittae and druse crystals in Steganotaenia fruits support a taxonomic affinity with the subfamily Saniculoideae (Apiaceae). South Afr. J. Bot. 73: 252-255.

Mohamed-Yasseen Y., Barringer S.A., Splittstoesser W.E. \& Costanza S. 1994. The role of seed coats in seed viability. Bot. Rev. 60: 426-439.

Rehman S., Harris P.J.C. \& Bourne W.F. 1998. The effect of sodium chloride on $\mathrm{Ca}^{2+}, \mathrm{K}^{+}$and $\mathrm{Na}^{+}$concentrations of seed coat and embryo of Acacia tortilis and Acacia coriacea. Ann. Applied Biol. 133: 269-279.

Shen Z.H., Tang Y.Y., Lü N., Zhao J., Li D.X. \& Wang G.F. 2007. Community dynamics of seed rain in mixed evergreen broad-leaved and deciduous forests in a subtropical mountain of central China. J. Integr. Plant Biol. 49: 1294-1303.

Skarpaas O. \& Stabbetorp O.E. 2001. Diaspore ecology of Mertensia maritima: effects of physical treatments and their relative timing on dispersal and germination. Oikos 95: $374-$ 382 .

Song J., Feng G., Tian C. \& Zhang F. 2005. Stratigies for adaptation of Suaeda physophora Haloxylon $\overline{\text { ammodon }} \overline{\text { dron }} \overline{\text { and }}$ Haloxylon persicum to a saline environment during seedgermination stage. Ann. Bot. 96: $\overline{399-405 .}$

Spalik K., Wojewódzka A. \& Downie S.R. 2001. The evolution of fruit in Scandiceae subtribe Scandicinae (Apiaceae). Can. J. Bot. 79: 1358-1374.

Ungar I.A.\& Khan M.A. 2001. Effects of bracteoles on seed germination and dispersal of Two Species of Atriplex. Ann. Bot. 87: 233-239.

Ungar I.A. 1978. Halophyte seed germination. Bot. Rev. 44: 233264.

Wolters M., Geertsema J., Chang E.R., Veeneklaas R.M., Carey P.D. \& Bakker J.P. 2004. Astroturf seed traps for studying hydrochory. Funct. Ecol. 18: 141-147.

Received October 29, 2008 Accepted April 24, 2009 